\title{
Syntaxonomy of the vegetation of National Nature Park Dzharylhatskyi. Classes Cakiletea maritimae and Ammophiletea
}

\section{Anastasia Davydova}

M. G. Kholodny Institute of Botany, National Academy of Sciences of Ukraine, Kyiv, Ukraine; anasta3Kz@gmail.com

Davydova A. (2019): Syntaxonomy of the vegetation of National Nature Park Dzharylhatskyi. Classes Cakiletea maritimae and Ammophiletea. - Thaiszia - J. Bot. 29 (2): 111-132

Abstract: The papers aims to clarify the syntaxonomic structure of communities of the halo-nitrophylous and annual vegetation within the coastal line of National Nature Park Dzharylhatskyi. Vegetation is represented by 6 associations, 1 subassociation and 1 basal community belonging to 2 alliances, 2 orders and 2 classes. The paper provides the classification scheme, phytocoenotic and synoptic tables, geobotanical profile and characteristics of associations. Furthermore, values of ordinal and phytoindicational analyses for 12 environmental factors are cited. Three syntaxa (associations Centaureo odessanae-Elymetum gigantei, Cakilo euxinae-Salsoletum tragi, subassociation Cakilo euxinae-Salsoletum tragi elytrigietosum bessarabicae) have been firstly indicated for this territory.

Keywords: syntaxonomy, ordination, phytoindication, coastal habitats, National Nature Park Dzharylhatskyi, Ukraine.

\section{Introduction}

The first mention of the coastal vegetation composition of the Dzharylhach Island appeared in 1928. Desiatova-Shostenko N. O. who paid attention to plant communities based on dominant principles limited in her papers only by a list of species charactered for these communities. Lack of interest to this vegetation type may explain the phrase: "Vegetation of littoral belts is very rare and varied; any plant dominates over the other, it does not matter much in aspect" (Desiatova-Shostenko \& Levin 1928). The author later describes the shore and sandy belt (Desiatova-Shostenko 1936). 
Syntaxonomic research of coastal vegetation of Dzharylhach based on the principles of ecological-floristic classification was begun and developed by Dubyna D. V. and Dziuba T. P. (Dubyna \& Dziuba 2005). Now within the class Cakiletea maritimae one order Euphorbietalia peplis R. Tx. 1950, one alliance Euphorbion peplis R. Tx. 1950 and three associations (Cakilo euxinaeEuphorbietum peplidis Dubyna et al. 1994, Cakilo euxinae-Salsoletum ruthenicae Vicherek 1971, Lactuco tataricae-Cakiletum euxinae Korzhenevsky et Kljukin 1990) were indicated for Ukraine (Dubyna et al. 2004; Dubyna et al. 2007). All these three associations were indicated for Dzharylhach Island too (Dubyna et al. 2004). In other paper devoted to the syntaxonomic diversity of the vegetation of Dzharylhach Island (Dubyna \& Dziuba 2005) the class Cakiletea maritimae is absent. In Syntaxonomy of vegetation of Ukraine by Solomakha V. A. (Solomakha 2008) a similar classification scheme of this class was proposed. Golub et al. (2006) described a new alliance Cakilo euxinae-Crambion maritimae Golub et al. 2006 from Azov coast of the Taman Peninsula, attributed to this syntaxon the associations Cakilo euxinae-Euphorbietum peplidis Dubyna et al. 1994 and Lactuco tataricae-Cakiletum euxinae (Korzhenevsky et Klyukin in Korzhenevsky 2001) Golub et al. 2006. Associations Cakilo euxinae-Salsoletum tragi Vicherek 1971 and Cakilo euxinae-Salsoletum ruthenicae Vicherek 1971 were included to the alliance Cakilion euxinae Géhu et al. 1994. Thus, for Cakiletea maritimae (indirectly affected of the vegetation of Dzharylhach) one new alliance was proposed, other one association was added and the one was validated (Dubyna et al. 2011).

Class Ammophiletea Br.-Bl. et Tx. ex Westhoff et al. 1946 was firstly indicated for Dzharylhach in the prodrome of vegetation of the Northern Black Sea for (as Honkenyo-Elymetea arenarii Tx. 1966). Five associations were cited for the island, but as stated in the paper of 2007 "...the data are based on the review of literature..." (Dubyna et al. 2004; 2007). Therefore, in the article The Phytocoenotic Diversity of Dzharylhach Island, the result of the processing of original geobotanical relevés was compiled and the classification scheme of vegetation was proposed, containing two associations and one community: Artemisietum arenariae Popescu et Sanda 1975; Elymetum gigantei Morariu 1957, Eryngium maritimum + Leymus sabulosus Comm. (Dubyna \& Dziuba 2005). The difference in the classification scheme of the class Ammophiletea in «Syntaxonomy of vegetation of Ukraine» by Solomakha V. O. is that instead of Crambetum maritimae Serbanescu 1970 association Crambo pontici-Leymetum sabulosi Tyschenko 1998 charactered for Azov spits was mentioned (Solomakha 2008).

Our work is relevant, because the research area has expanded in consequence of the creation of National Nature Park Dzharylhatskyi, there is the capability to explore dynamic changes in comparison with previous papers. The basic concern of the work is to develop a classification scheme and prodrome of the natural vegetation of coastal area of National Nature Park Dzharylhatskyi, synphytoindication and ordination of communities within the classes Cakiletea maritimae and Ammophiletea. 


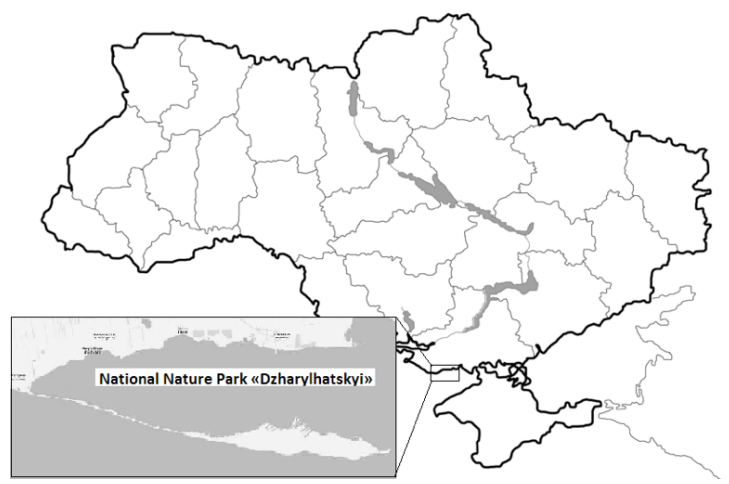

Fig. 1. The location of National Nature Park Dzharylhatskyi in Ukraine.

\section{Materials and methods}

National Nature Park (NNP) Dzharylhatskyi is situated in the south-eastern climatic region of Ukraine. The main features of climate are the predominance of eastern and north-eastern winds, relatively low humidity, low cloud cover, low rainfall and relatively high daily and annual amplitudes of air temperature fluctuations (Ardamatskaya et al. 2000; Proect 2015). There is the one type of vegetation in this area according to the Map of the natural vegetation of Europe; it is western and central Pontic desert steppes (Bohn et al. 2004).

The study is based on data of field work conducted in 2015 and 2017. 82 relevés on from 5 to $25 \mathrm{~m}^{2}$ plot size were sampled on studied area according to the Braun-Blanquet approach (Braun-Blanquet 1964; Westhoff \& van der Maarel 1973). The ecological-floristic classification was carried out using the deductive method of Kopecký-Hejný, which is expedient to use for synanthropic and weakly overgrown disturbed or undisturbed natural, especially dynamic communities (Kopecký \& Hejný 1974). Vegetation classification was conducted by Modified TWINSPAN (Roleček et al. 2009) implemented in the software package JUICE 7.0 (Tichý 2002). The features of ecological differentiation of communities were detected by DCA-ordination method (Hill \& Gauch 1980) using the R-project program. To clarify the attitude of communities to main ecological factors the statistical analysis in the STATISTICA 7.0 program was used based on the ecological scales of Ya.P. Didukh (Didukh 2011).

We used the modified scale of the coverage for plant species by B. M. Mirkin: $+-<1 \%, 1-1-5 \%, 2-6-15 \%, 3-16-25 \%, 4-26-50 \%, 5->50 \%$ (Mirkin \& Rosenberg 1983). The class of species constancy is defined by the scheme: I $\leqslant 20 \%$; II - 21-40 \%; III - 41-60 \%; IV -61-80\%; V-81-100\% (Mirkin et al. 2001).

To identify diagnostic species the phi fidelity index was used (Chytrý et al. 2002). Non-essential values of fidelity (less than 0.001 ) were removed on the basis of Fischer's exact test. The fidelity threshold for the allocation of diagnostic species is at least $25 \%$, for highly diagnostic species $-50 \%$. Syntaxa were compared 
with similar communities described on other coasts and islands of the Black Sea, both in Ukraine and abroad. As an indicator of floristic similarity, the coefficient of Jaccard was used.

The names of syntaxa were used according to the International Code of Phytosociological Nomenclature (Weber et al. 2000). Plant species names follows Vascular plants of Ukraine. A nomenclatural checklist (Mosyakin \& Fedoronchuk 1999). Several taxa, which names are need to be clarified, were indicated with references to relevant sources (Mavrodiev et al. 2015; Mosyakin 2017).

\section{Results}

According to the EuroVegChecklist the alliance Cakilo euxinae-Crambion maritimae Golub et al. 2006 is synonym of Cakilion euxinae Géhu et al. 1994, Thero-Atriplicetalia Pignatti 1953 is validly published but it is syntaxonomic synonym of the order Euphorbietalia peplidis Tx. 1950 (Mucina et al. 2016). Changes concerned the years of valid publication of syntaxa are presented in our classification scheme.

During the searching for an original description of the association Artemisietum arenariae Popescu et Sanda 1975 we found that this syntaxon was described later, in 1977 in the paper "Contribuții noi la cunoaşterea vegetației litoralului românesc al Mării Negre", therefore, instead of reference to 1975 widely used in Ukrainian sources, we indicate the name Artemisietum arenariae Popescu et Sanda 1977.

Since this work is attributed to coastal areas, we include a proposal for the inexpediency of inclusion the class Crithmo-Staticetea Br.-BI. 1947 (now Crithmo-Staticetea Br.-BI. in Br.-Bl. et al. 1952) (Dubyna \& Dziuba 2005; Mucina et al. 2016) in the classification scheme of vegetation of the NNP Dzharylhatskyi (association Lactuco tataricae-Elytrigietum bessarabicae Korzhenevsky et Klyukin in Korzhenevsky 2001). The original diagnosis of this association includes two species (Elytrigia bessarabica (Savul. \& Rayss) Prokud. and Lactuca tatarica (L.) C.A. Mey.) which are present on Dzharylhach Island but they have the differences in ecological conditions. Elytrigia bessarabica grows mainly on sands of the northern coast of Black Sea, Lactuca tatarica - on the shellfish sediments of the southern coast. There is no Crithmum maritimum L. in the island's flora, which is typical species for the alliance, order and class Crithmo-Staticetea (Korzhenevsky 2001).

\section{The classification scheme of coastal halo-nitrophylous and psammophytic vegetation of National Nature Park Dzharylhatskyi:}

Cl. Cakiletea maritimae Tx. et Preising in Tx. ex Br.-Bl. et Tx. 1952

- Ord. Thero-Atriplicetalia Pignatti 1953

- All. Cakilion euxinae Géhu et al. 1994

- Ass. Lactuco tataricae-Cakiletum euxinae Korzhenevsky et Klyukin in Korzhenevsky 2001

- Ass. Cakilo euxinae-Salsoletum tragi Vicherek 1971

- Subass. Cakilo euxinae-Salsoletum tragi elytrigietosum

bessarabicae Korzhenevsky et Klyukin in Korzhenevsky 2001 


\section{Cl. Ammophiletea Br.-Bl. et Tx. ex Westhoff et al. 1946}

- Ord. Ammophiletalia Br.-BI. et Tx. ex Westhoff et al. 1946

- All. Elymion gigantei Morariu 1957

- Ass. Tournefortietum sibiricae Popescu et Sanda 1975

- Ass. Elymetum gigantei Morariu 1957

- BC Poacynum russanovii [Elymion gigantei]

- Ass. Artemisietum arenariae Popescu et Sanda 1977

- Ass. Centaureo odessanae-Elymetum gigantei Vicherek 1971

The class Cakiletea maritimae represents the pioneer halo-nitrophylous vegetation of sandy seaside forming near the upper boundary of the beach. Diagnostic species are Cakile maritima subsp. euxina (Pobed.) E. J. Nyárády, Crambe maritima L., Euphorbia peplis L., Polygonum maritimum L., Salsola squarrosa subsp. pontica (Pall.) Mosyakin (Mucina et al. 2016). The alliance Cakilion euxinae is represented by halo-nitrophylous communities of the southern coast of Dzharylhach Island forming in the zone of influence of storms. The class was cited firstly for NNP in 2017 (Shaposhnikova 2017).

\section{Ass. Lactuco tataricae-Cakiletum euxinae Korzhenevsky et Klyukin in Korzhenevsky 2001}

Diagnostic species: Cakile maritima subsp. euxina, Lactuca tatarica Constant species: Centaurea odessana, Crambe maritima, Eryngium maritimum, Euphorbia peplis, Gypsophila perfoliata, Leymus sabulosus, Suaeda prostrata Dominant species: Leymus sabulosus

The association was firstly invalidly described in 1990 by Korzhenevsky V. $\mathrm{V}$. and Klyukin O. A. based on data collected in the northern coast of Kerch Peninsula (the Crimea). In 2001, Korzhenevsky V. V. validated it in accordance with ICPN requirements (Korzhenevsky \& Klyukin 1990; Korzhenevsky 2001). This communities are pegged to the sandy-shell hilly areas. Within NNP it is rare, distributed mainly on the coasts of the island from Dzharilgatsky bay. Total plant cover of these communities is about $30 \%$. The number of species is 18 (about 7 in one relevé). The coefficient of floristic similarity between the relevés in the original diagnosis and the author's is $43 \%$. This syntaxon, except of Ukraine (Arabatska spit, Biriuchiy Island, Obytichna spit, Aktash lake), is found on the Azov coast in Russian Federation (Dolgaya spit, Achyevskaya spit).

\section{Ass. Cakilo euxinae-Salsoletum tragi Vicherek 1971}

Diagnostic species: Cakile maritima subsp. euxina, Salsola squarrosa subsp. pontica

Constant species: Crambe maritima, Eryngium maritimum, Lactuca tatarica, Leymus sabulosus, Polygonum maritimum

Dominant species: Eryngium maritimum, Leymus sabulosus

The association was described by Vicherek J. (1971) based on his relevés from the coast of the Yagorlytsky estuary and the islands of Dovhyi, Orlov and Tendra. In NNP Dzharylhatskyi this communities were observed on alluvial areas, the initial stages of forming littoral shaft, sporadically distributed on the coast of the Dzharylhach Island from the open sea. Total cover of these communities 
is about $30 \%$. The number of species is 10 (ranges from 2 to 7 in one relevé). The coefficient of floristic similarity between the relevés in the original diagnosis and the author's is 53 \%. Except the typical Cakilo euxinae-Salsoletum tragi next subassociaction has been discovered.

\section{Subass. Cakilo euxinae-Salsoletum tragi elytrigietosum bessarabicae Korzhenevsky et Klyukin in Korzhenevsky 2001}

Diagnostic species: Cakile maritima subsp. euxina, Elytrigia bessarabica, Salsola squarrosa subsp. pontica

Constant species: Eryngium maritimum

Dominant species: Cakile maritima subsp. euxina

The subassociation was described by Korzhenevsky \& Klyukin (1990) based on materials from the northern coast of Kerch Peninsula and validated in 2001 (Korzhenevsky \& Klyukin 1990; Korzhenevsky 2001). Habitats of this coenosis are concentrated in the southwestern part of the island (spit). Partially it coincides with the area of Cakilo euxinae-Salsoletum tragi, but communities of the subassociation were observed on the higher parts of beach on formed alluvial hills. Total cover of these communities is $25 \%$ almost on all plots. The number of species is 6 (about 4 in one relevé). The coefficient of floristic similarity between the relevés in the original diagnosis and the author's is $45 \%$. The syntaxon is presented now only for the territory of Ukraine.

The class Ammophiletea is represented by communities on moving sand dunes, which are quite dynamic forms of relief due to eolian processes. Diagnostic species are Argusia sibirica (L.) Dandy, Carex colchica J. Gay, Eryngium maritimum L., Leymus sabulosus (M. Bieb.) Tzvelev (Mucina et al. 2016; Herrera et al. 2018). On the studied territory the alliance Elymion gigantei is represented by the vegetation of seaside belt and coastal dunes on the southern coast.

\section{Ass. Tournefortietum sibiricae Popescu et Sanda 1975}

Diagnostic species: Argusia sibirica, Lactuca tatarica, Puccinellia gigantea, Suaeda prostrata, Tripolium vulgare

Constant species: Cynanchum acutum, Leymus sabulosus, Salsola squarrosa subsp. pontica

Dominant species: Argusia sibirica

The original diagnosis of this association includes the coastal relevés made near Năvodari town in Romania (Popescu \& Sanda 1975). These communities are distributed in NNP on loose sands of the foot of the littoral belt or on dense soils of sand and shelly facies (within the island - on the side of the bay). Total cover of plots of this association is $50 \%$. The number of species -17 (from 4 to 10 in one relevé). The coefficient of floristic similarity between the relevés from Romanian Black Sea Coast and the author's is 85 \%. Except Ukraine and Romania, Tournefortietum sibiricae was found also in the southern Caspian coast of Iran and on the Black Sea coast of Bulgaria (Fagaras 2012; Naqinezhad 2012). 


\section{Ass. Elymetum gigantei Morariu 1957}

Diagnostic species: Leymus sabulosus, Polygonum maritimum

Constant species: Eryngium maritimum, Euphorbia seguieriana, Salsola squarrosa subsp. pontica

These communities grows on the slopes of littoral belt or on its top. If we compare them with other littoral vegetation, it is more dependent on deflationary processes rather than by water erosion. The largest areas these coenoses occupy in the middle part of the island, where sand is accumulated and new areas of beach are formed. Total plant cover is sparse, on average 30-35\%. Floristic diversity is 16 species (4-6 in one relevé). The coefficient of floristic similarity between the relevés in the original diagnosis and the author's is $36 \%$, in comparison with modern relevés from Romania (Popescu \& Sanda 1975), this coefficient is $89 \%$. Except the Ukraine and Romania, this association is widespread on the Black Sea coast in Bulgaria and Russian Federation (Popescu \& Sanda 1975; Fagaras 2012).

\section{$\mathrm{BC}$ Poacynum russanovii [Elymion gigantei]}

Diagnostic species: Phragmites australis, Poacynum russanovii

Constant species: Artemisia arenaria, Calamagrostis epigejos, Carex colchica, Euphorbia seguieriana, Leymus sabulosus, Picris hieracioides

Dominant species: Artemisia arenaria, Poacynum russanovii

Poacynum russanovii (Pobed.) Mavrodiev, A. Laktionov et Y. Alexeev (synonym - Trachomitum venetum (Pobed.) Pobed.) is endemic species, sometimes considered as a subspecies (Mavrodiev 2015). We have identified the basal community BC Poacynum russanovii [Elymion gigantei], observed on the dune tops and inner slopes in the southwestern part of the island (spit). But it grows as a dominant in damp depressions too along with Phragmites australis (Cav.) Trin. ex Steud. Total herb cover is $50 \%$. The number of species is 26 (from 6 to 11 in one relevé).

\section{Ass. Artemisietum arenariae Popescu et Sanda 1977}

Diagnostic species: Artemisia arenaria

Constant species: Carex colchica, Centaurea odessana, Eryngium maritimum, Leymus sabulosus, Salsola squarrosa subsp. pontica, Secale sylvestre

Dominant species: Artemisia arenaria, Eryngium maritimum

The association is firstly described by Popescu A. and Sanda V. from the littoral vegetation of the Romanian coast of the Black Sea (Sanda et al. 2008). These communities are characterized for old high dunes in the southwestern part of the island (spit), several locations are known from the eastern outskirts. Total herb cover is sparse, on average $45-50 \%$. The number of species - 17 (about 6-7 in one relevé). Similar communities are distributed on the territory of Azerbaijan, Iran and Romania (Atamov 2008; Naqinezhad 2012; Fagaras 2015).

\section{Ass. Centaureo odessanae-Elymetum gigantei Vicherek 1971}

Diagnostic species: Centaurea odessana, Leymus sabulosus 


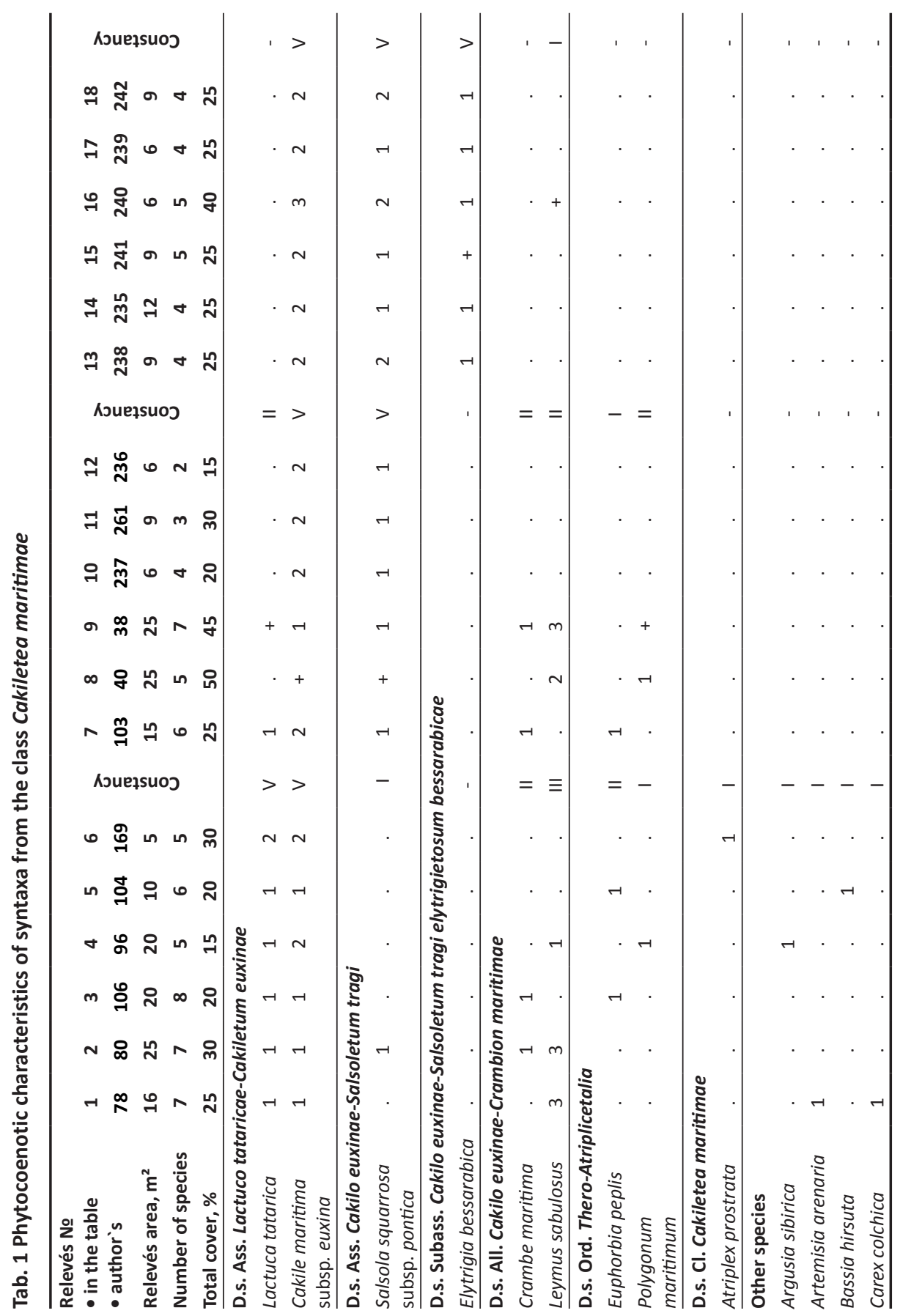




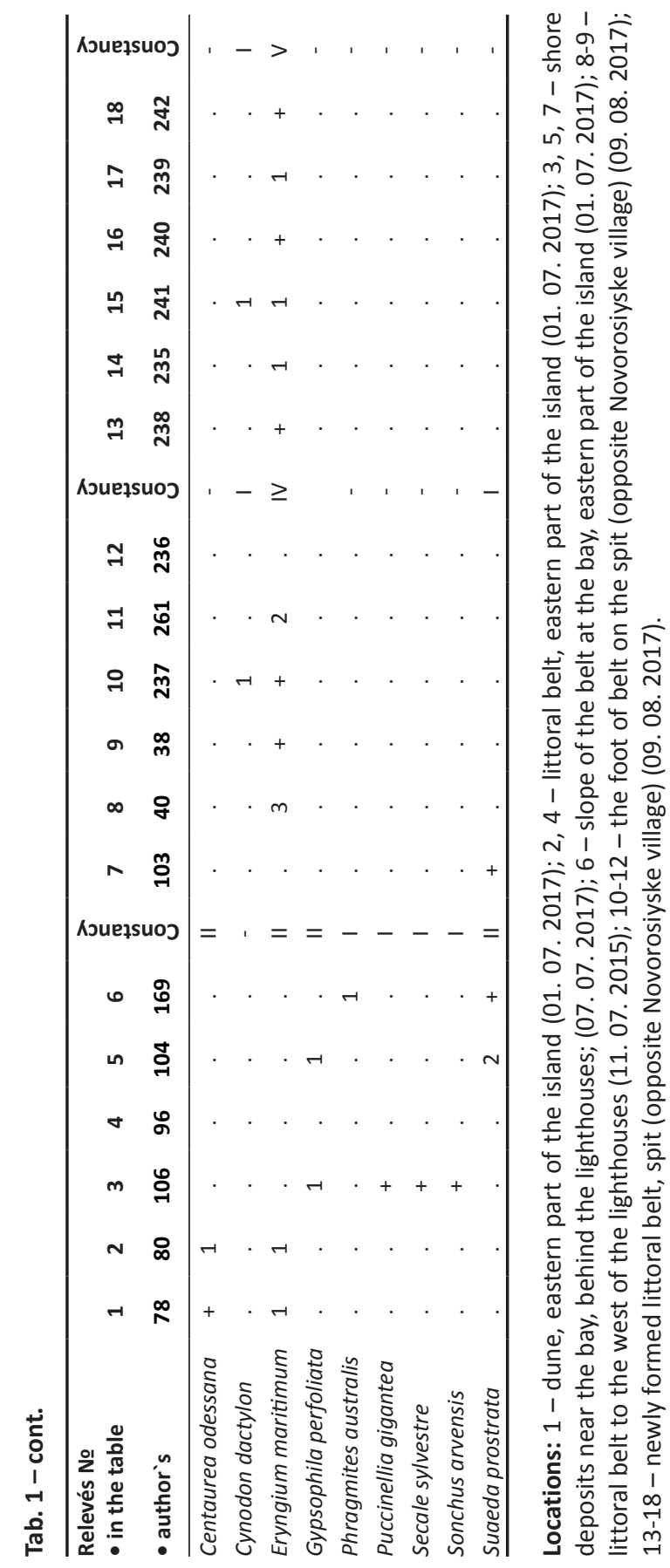




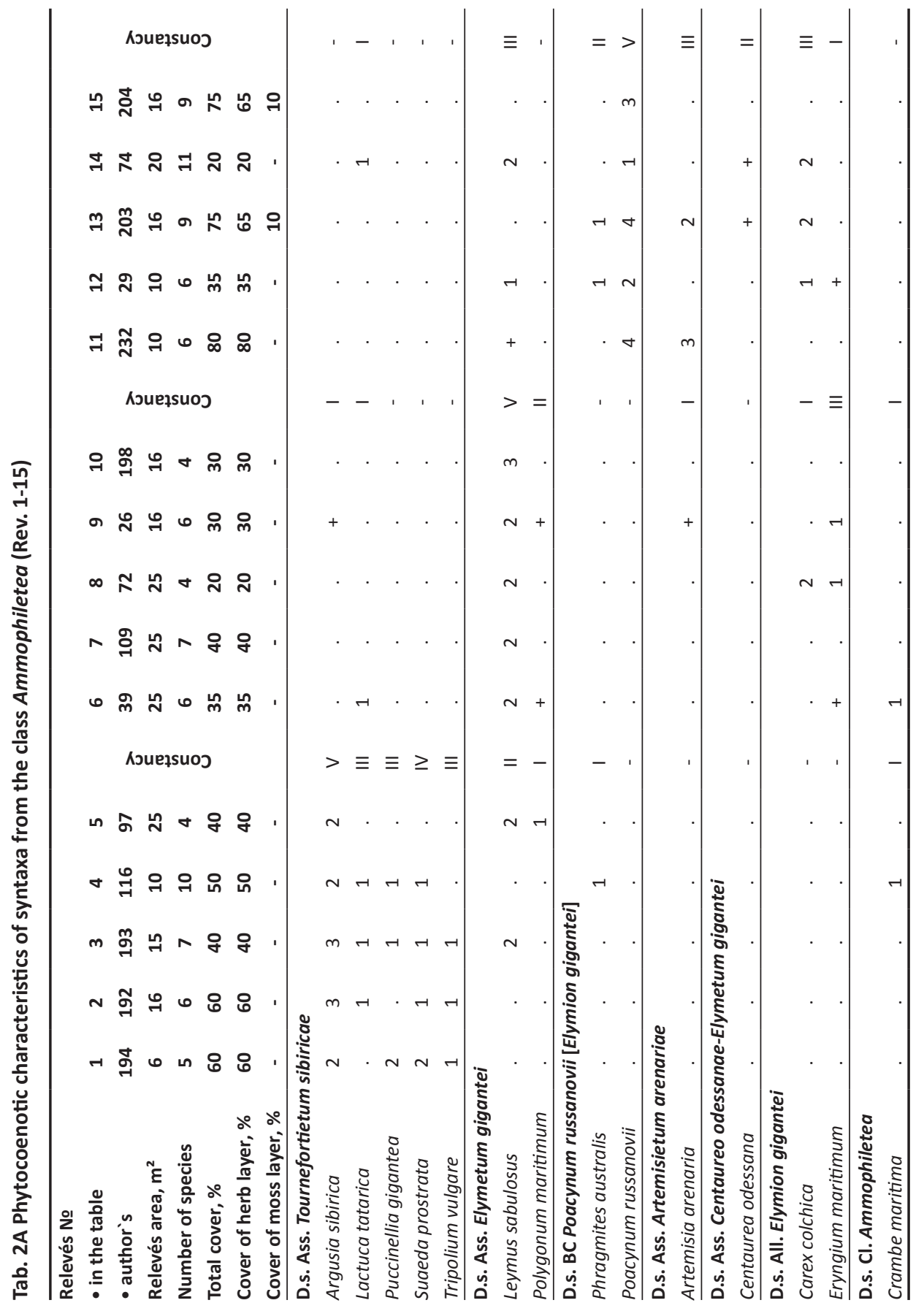




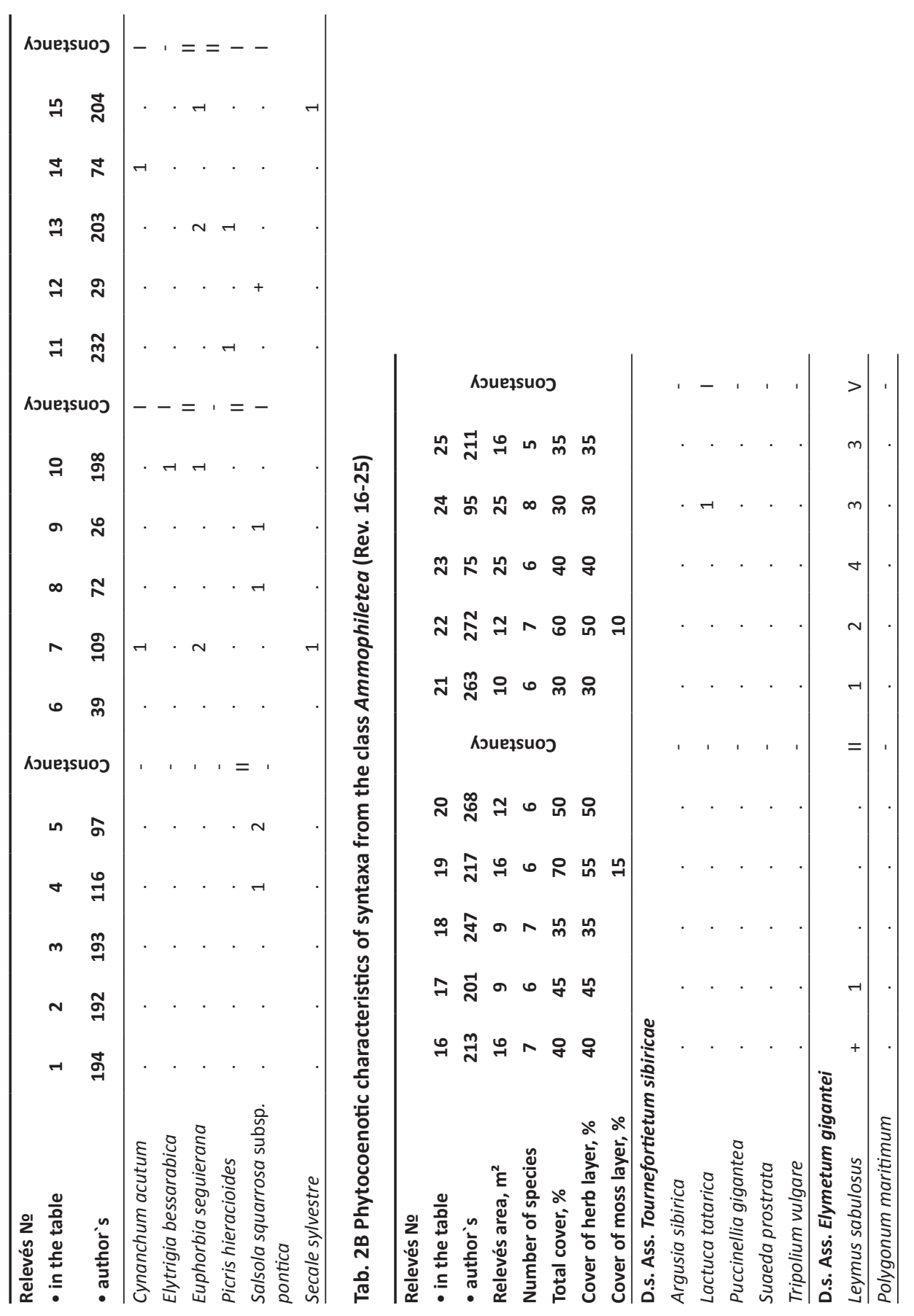




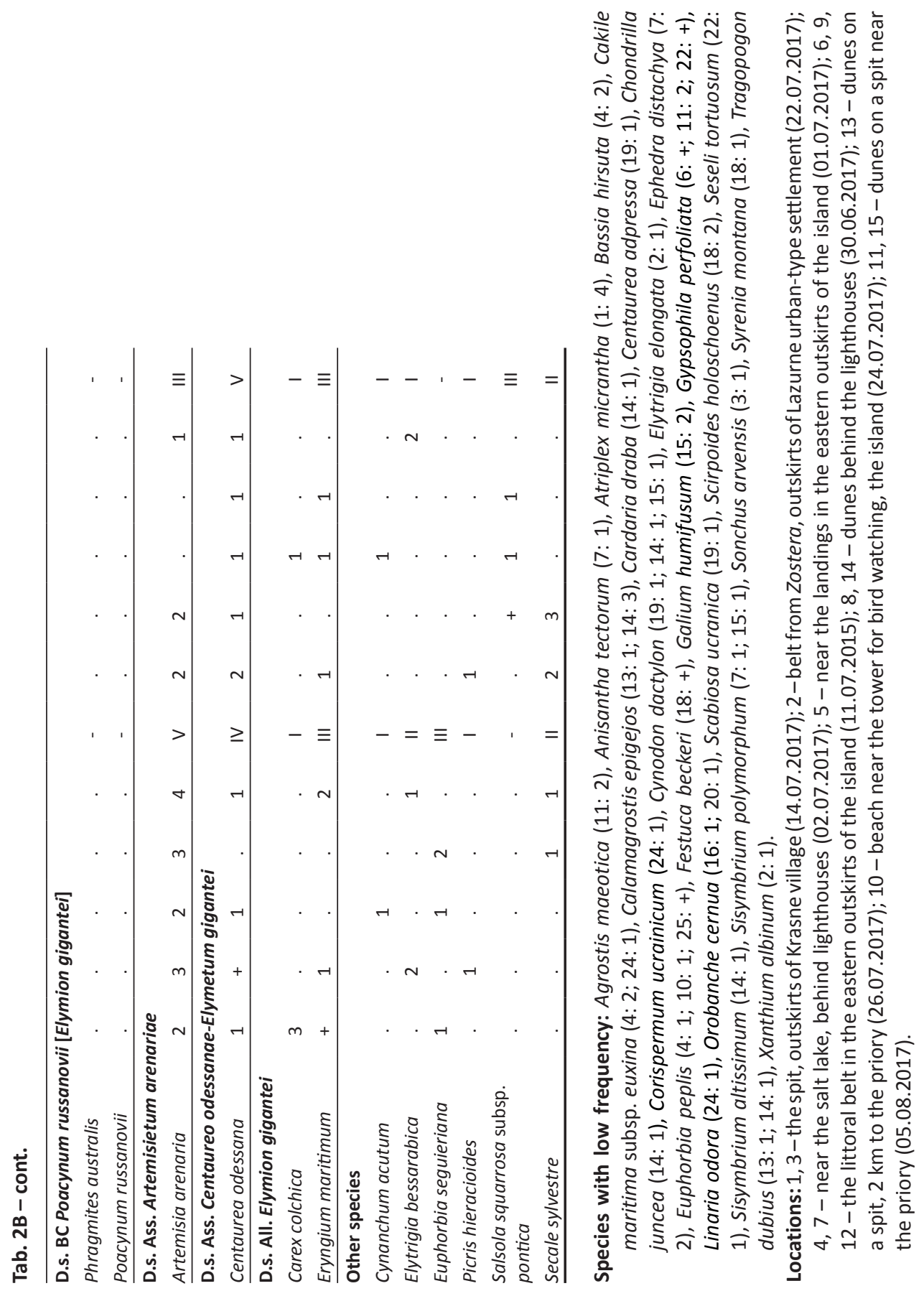




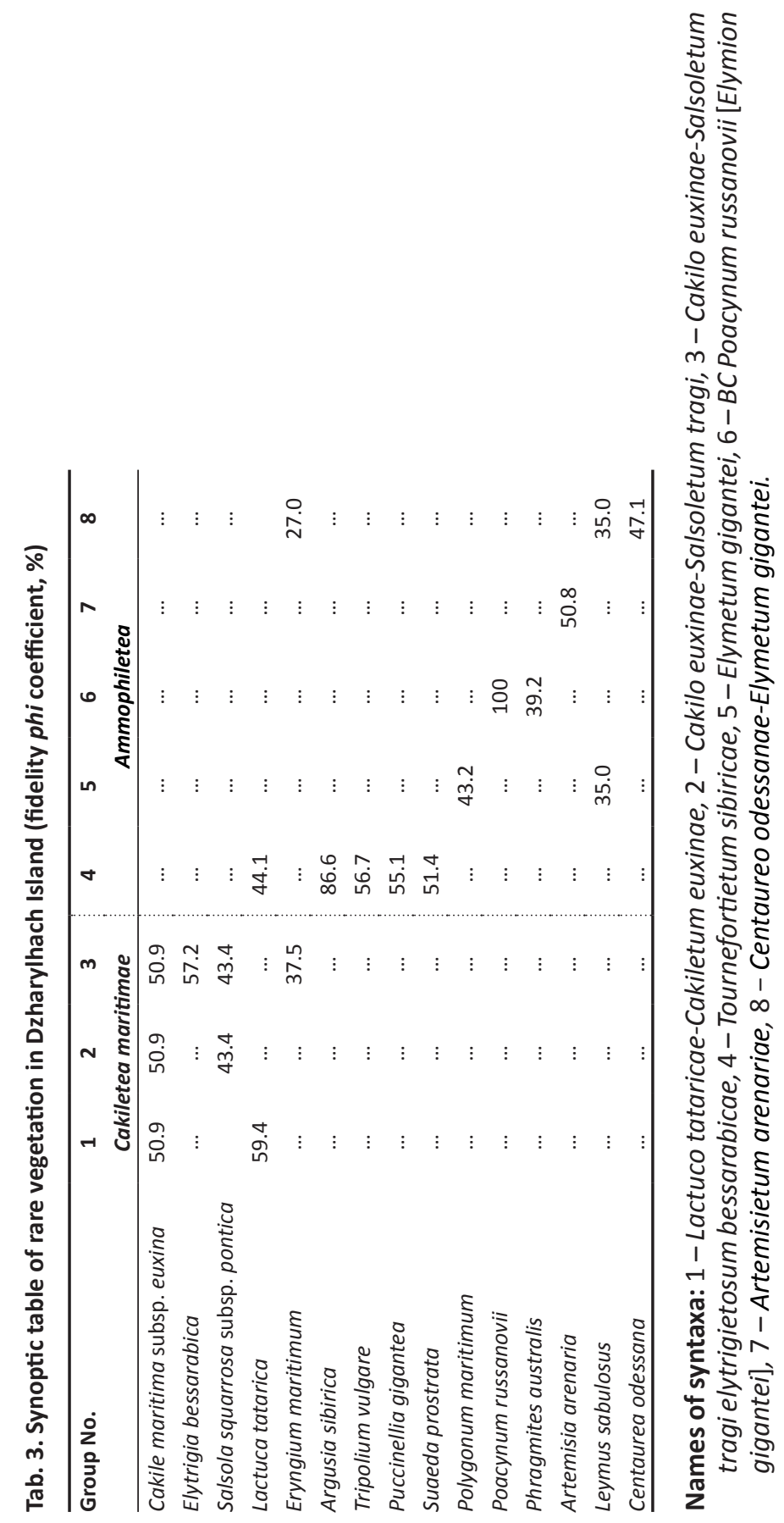


Tab. 4. Values of environmental factors (by Didukh 2011)

\begin{tabular}{|c|c|c|c|}
\hline Ecological factors & $\min$ & med & $\max$ \\
\hline $\begin{array}{l}\text { Soil water regime } \\
\text { (Hd) }\end{array}$ & Hyper-xerophytes (1) & Mesophytes (11) & Hyper-hydrophytes (23) \\
\hline Soil acidity (Rc) & Hyper-acidophiles (1) & Sub-acidophiles (7) & Hyper-basophiles (15) \\
\hline Salt regime (SI) & Oligotrophes (1) & Eutrophes (9) & Super-halotrophes (19) \\
\hline $\begin{array}{l}\text { Carbonate content } \\
\text { (Ca) }\end{array}$ & Hyper-carbonatephobes (1) & Hemi-carbonatophobes (5) & Hyper-carbonatophiles (13) \\
\hline Soil aeration (Ae) & Hyper-aerophiles (1) & Hemi-aerophobes (7) & Hyper-aerophobes (15) \\
\hline Thermoregime (Tm) & Hekistotherms (1) & Sub-mesotherms (9) & Megatherms (17) \\
\hline $\begin{array}{l}\text { Continental climate } \\
\text { (Kn) }\end{array}$ & Extra-oceanic (1) & Hemi-continental (9) & Ultra-continental (17) \\
\hline
\end{tabular}

Constant species: Artemisia arenaria, Carex colchica, Cynanchum acutum, Eryngium maritimum, Lactuca tatarica, Salsola squarrosa subsp. pontica Dominant species: Cynanchum acutum, Leymus sabulosus

The association was firstly described in the paper by Vicherek J. (1971) with four subassociations. It is characterized for internal slopes or aligned tops of dunes in the southwestern part of the island (spit). Total cover of these communities reaches $40 \%$ almost on all plots. The number of species is 17 (6-7 in one relevé). The syntaxon is present only on the territory of Ukraine (Vicherek 1971).

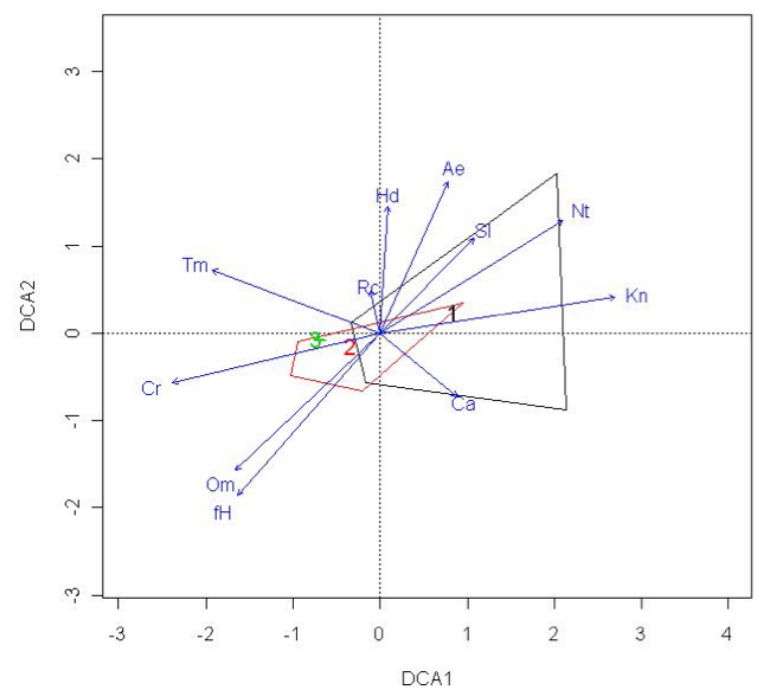

Fig. 2 Results of DCA-ordination of syntaxa of the class Cakiletea maritimaea: 1 - Lactuco tataricae-Cakiletum euxinae, 2 - Cakilo euxinae-Salsoletum tragi, 3 -Cakilo euxinae-Salsoletum tragi elytrigietosum bessarabicae 
DCA-ordination of Cakiletea maritimaea communities shows that the differentiation of syntaxa occurs according to edaphic factors: acidity (Rc) and soil water regime $(\mathrm{Hd})$ and they are sensitive to changes in climate continentality (Kn) (Fig. 2). The phytodynamic analysis of soil water regime (Hd) showed that the vegetation of this class is xeromesophytic (5-11 grade) (Tab. 4). The largest range of scattering ( 3.1 grade) was recorded in the association Cakilo euxinae-Lactucetum tataricae, in Cakilo euxinae-Salsoletum tragi elytrigietosum bessarabicae quartiles did not diverge because indicators are similar (10.4 grade). The gradient of soil water regime in communities varies according to topography and habitat. As for the differentiation of plant communities on soil acidity (Rc) the average range between quartiles demonstrates that acceptable is alkaline ( $\mathrm{pH}=7.2-7.7)$ (11 grade). The scattering range is greatest in Lactuco tataricae-Cakiletum euxinae (9.4-12.0 grade), similar in sub-basophilic Cakilo euxinae-Salsoletum tragi and Cakilo euxinae-Salsoletum tragi elytrigietosum bessarabicae (10.9-11.7 and 11.9-11.4 grades respectively). The continental climate $(\mathrm{Kn})$ is similar to the difference between the maximum and minimum values of Cakilo euxinae-Salsoletum tragi and its subassociation - 6.1-7.0 grade correlated with suboceanic ecogroups. The vegetation of Lactuco tataricaeCakiletum euxinae association has the widest range of scattering (7.1-10.1 grade), it represents a value from hemioceanic to hemicontinental (7-9 grade).

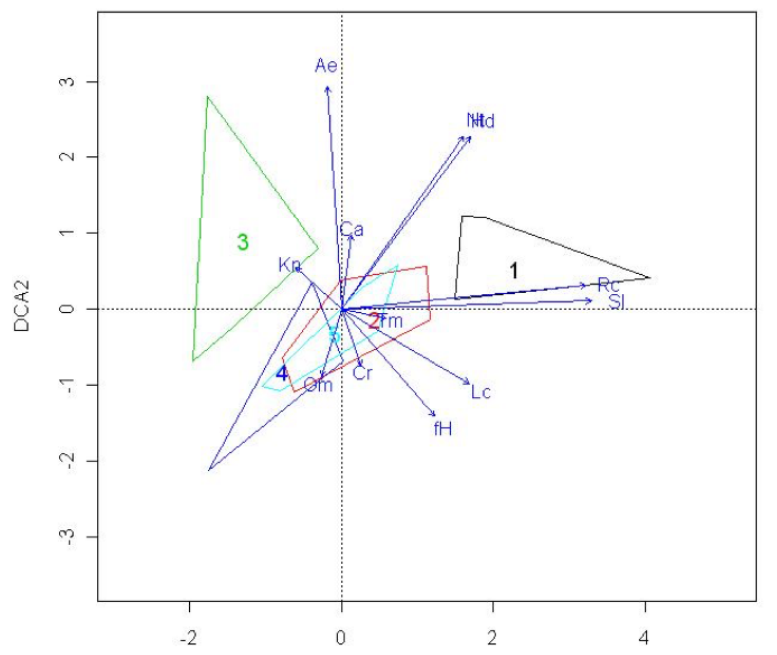

Fig. 3 Results of DCA-ordination of syntaxa from the class Ammophiletea: 1 - Tournefortietum sibiricae, 2 - Elymetum gigantei, 3 - Centaureo odessanae-Elymetum gigantei, 4-Artemisietum arenariae, 5 - BC Poacynum russanovii [Elymion gigantei] 
The DCA-ordination of communities of the Ammophiletea shows that the differentiation of syntaxa occurs mainly on the indicators of edaphic factors: aeration of soil $(\mathrm{Ae})$, salt regime $(\mathrm{SI})$, carbonate content $(\mathrm{Ca})$, acidity $(\mathrm{Rc})$, and they are sensitive to the thermal climate regime (Tm) (Fig. 3).

By soil aeration measures (Ae), communities of Tournefortietum sibiricae, growing on packed soils, due close to the breaker line are hemi-aerophobes (6.36.9 grade) (Tab. 4). The greatest difference between quartiles and extreme values in Centaureo odessanae-Elymetum gigantei (5.5-7.9 grade) can be explained by the peculiarities of the relief (growth on the rise, and on the depressions protected by the littoral belt). The similar data (4.9-5.7 grade) were shown by subaerophylic Elymetum gigantei, Artemisietum arenariae, BC Poacynum russanovii, which grow on littoral belt, tops of the sand dunes of the beach etc. The differentiation of vegetation by acidity (Rc) determines that the acidic media is acceptable for Tournefortietum sibiricae (10.5-11.7). The scattering range is largest in Elymetum gigantei (9.1-11.5 grade), similar in neutrophil Centaureo odessanae-Elymetum gigantei and Artemisietum arenariae (8.1-9.5 and 8.49.5 grade, respectively). The results of the analysis of the total salt regime diagrams (SI) correlate with the position of the communities in microrelief: Tournefortietum sibiricae often subjected to direct influence of sea water has the highest levels of salt content in the soil (12.2-14.8 grade). The lowest rates of salt regime (soils poor in salt content) was found in Centaureo odessanaeElymetum gigantei (9-10.6 grade). Accordingly in Elymetum gigantei the widest range of scattering is due to the relatively broad range of growth compared with other coastal groups (10.5-13.8 grade) and the medians of Artemisietum arenariae (9.1-12.4 grade) and BC Poacynum russanovii (10.6-11.3 grade) are at the same level although there are differences in the values of quartiles. The vegetation of Ammophiletea by the carbonate content $(\mathrm{Ca})$ is different from hemicarbonatophobes to acarbonatophils (5-7 grade). Significant scattering was recorded only in Elymetum gigantei (5.2-7.61 grade). In our opinion it is also due to the limits of growth. All other analyzed groups are similar in value to soils with low content of $\mathrm{Ca}(\mathrm{CaO}, \mathrm{MgO}=0,5-1,5 \%)$. For thermal climate regime $(\mathrm{Tm})$ communities of Ammophiletea are within submesotherms and mesotherms (1884-2303 m²/year). The largest dispersion in Elymetum gigantei (9.8-11.3 grade) may be due to the uneven distribution of solar radiation due to differences in microrelief.

\section{Discussion}

To reveal the features of marine-dune vegetation of Dzharylhach Island our results were compared with existing data about Tendra Island (Umanets \& Solomakha 1999). On Tendra Island classes Cakiletea maritimae and Ammophiletea are represented too, but syntaxa from the latter class are considered within Festucetea: D.c. Elytrigia elongata+Leymus sabulosus, Artemisia arenaria+Elytrigia nodosa. The vegetation of Cakiletea maritimae on Tendra Island is represented by Lactuco tataricae-Cakiletum euxinae and Cakilo euxinae-Salsoletum ruthenicae Vicherek 1971. Since in the phytocoenotic tables 
Salsola australis was indicated currently accepted as S. tragus L. we consider these relevés as Cakilo euxinae-Salsoletum tragi Vicherek 1971.

Jaccard coefficient of the floristic similarity between typical variant of Cakilo euxinae-Salsoletum tragi from islands of Dzharylhach and Tendra is $92 \%$, variant of Elytrigia bessarabica - $86 \%$, in comparison with modern relevés from Romania this coefficient is $89 \%$. Jaccard coefficient of the floristic similarity for Lactuco tataricae-Cakiletum euxinae between relevés from islands of Tendra and Dzharylhach is $75 \%$. The comparison of the annual vegetation in shoreline of Dzharylhach Island with the spits in the Azov Sea has shown a predominance of halophylous component. Ammophiletea class is represented by specific associations of Azov sea coastal line - Crambo-pontici-Leymetum sabulosi Tyshchenko 1998 and two derivate communities of Elymion gigantei (Tyshenko 2006).

The role of species from the genus Poacynum Baill. (=Trachomitum Woodson) in littoral communities (Ammophiletea) of Black and Mediterranean seas is deficiently known. Trachomitum venetum one of the dominant in Elymion gigantei communities in Bulgaria; it is a component of subassociation TortuloScabiosetum apocynetosum in Italy; communities $T$. venetum + Sporobolus virginicus and association Ipomaeo stoloniferae-Sporobolus virginicus was reported from Turkey (Çakan et al. 2011; Tzonev 2011; Kolomiychuk 2013; Sburlino et al. 2013).

Communities of Cakiletea maritimae is represented by certain diagnostic species but no lower syntaxa were allocated on the spits. Probably the difference between the riches and the maturity of halo-nitrophylous and psammophytic vegetation of Black Sea islands of Dzharylhach and Tendra and Azov spits can be explained by the areas of the shoreline, the features of the abrasive activity of Black and Azov Seas, water salinity. Comparison of Cakiletea maritimae and Ammophiletea floristic structure with the data from the original diagnoses showed that by the number of species they are as 1.5:1.4 and 3:2.3 respectively. If the slight differences in the species composition of Cakiletea maritimae from different regions is explained by higher level of nitrogen, then the difference in Ammophiletea is explained by the significant presence halophylous component in Romanian data.

As a result of primary overgrowth of newly formed linksland, pioneer vegetation of Cakiletea maritimae is replaced by coenoses of the class Ammophiletea inhabited the littoral belt. One of the examples of spatial differentiation of shoreline vegetation communities illustrated on the geobotanical profile of the western narrow part of the Dzharylhach Island (Fig. 4). The halo-nitrophylous communities of Cakilo euxinae-Salsoletum tragi, which are the closest to the coastline, are gradually replaced by more xerophytic subassocation Cakilo euxinae-Salsoletum tragi elytrigietosum bessarabicae, which occupies the higher parts of the sandy beaches. The foot and the slope of the littoral belt are characterized for Elymetum gigantei. In the wide part of the island communities of Elymetum gigantei occupy a large areas and they are gradually changing by psammophytic steppe vegetation (Festucetea vaginatae) on flat dunes. However, the narrow part of the island (spit) is characterized by high dunes. The belt, as a 


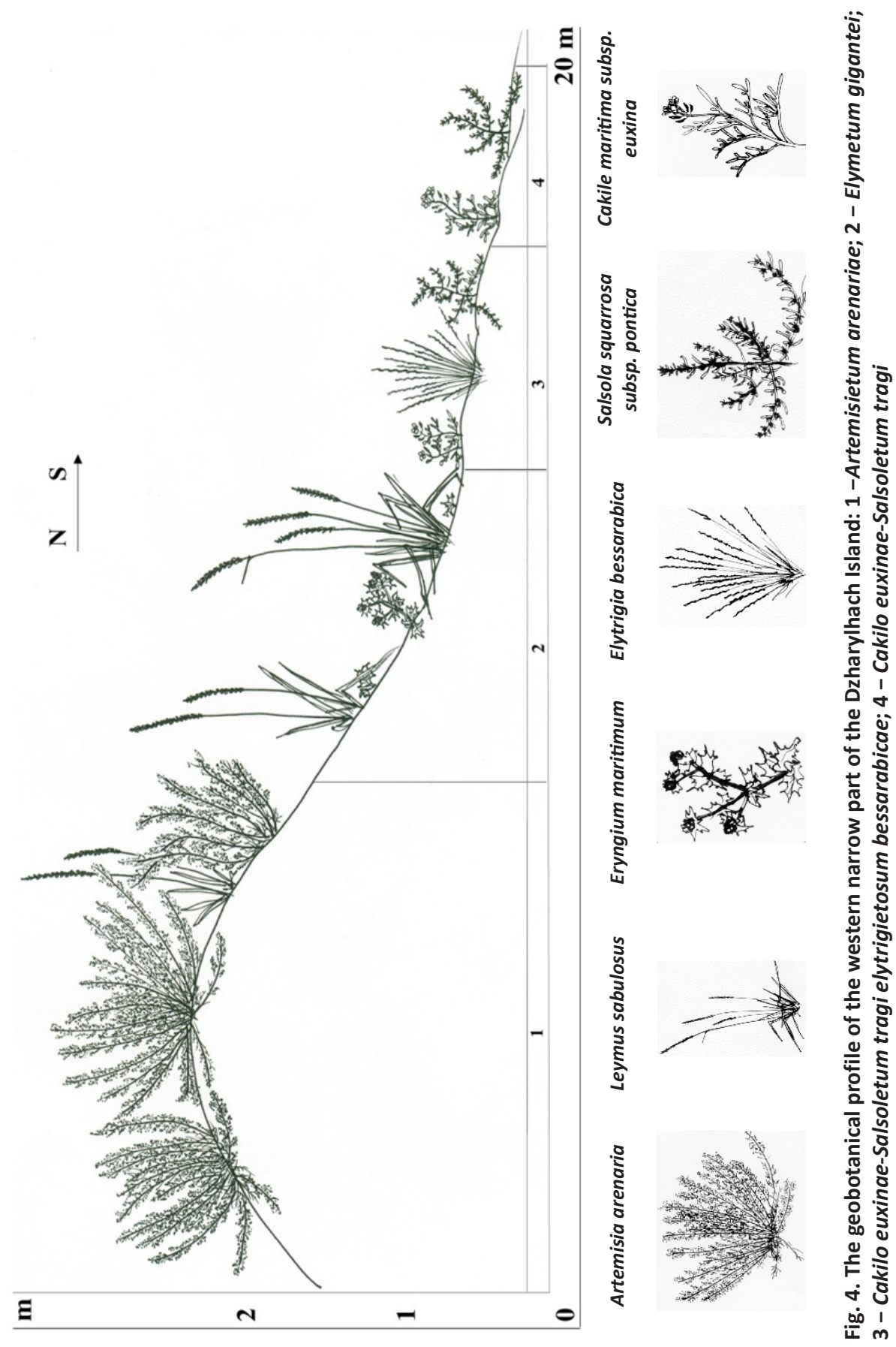


rule, immediately changed by dunes with Artemisietum arenariae on the top and on inner slopes. Since at this stage the influence of recreational activity on these type of vegetation there is no effect, the only stimulating factor of syndynamics is natural. Namely - water and wind erosion (abrasion of the seaside and alluvial and deflation processes). On some broken by storms areas of the southern coast of the island series begins from Elymetum gigantei or Artemisietum arenariae. They differ from typical communities because they have great coverage and sometimes do not have distinct limits.

\section{Conclusions}

The existing classification scheme of coastal vegetation of Dzharylhach Island was supplemented and corrected. The syntaxonomic structure of the halo-nitrophylous (Cakiletea maritimae) and psammophytic (Ammophiletea) vegetation of National Nature Park Dzharylhatskyi was specified. It is represented by 6 associations, 1 subassociation and 1 basal community belonging to 2 alliances, 2 orders and 2 classes. New syntaxa for the national nature park are associations Centaureo odessanae-Elymetum gigantei, Cakilo euxinae-Salsoletum tragi and subassociation Cakilo euxinae-Salsoletum tragi elytrigietosum bessarabicae. A degree of floristic similarity for all syntaxa was determined between studied communities in Ukraine and other countries. The ecological analysis revealed the leading factors of the spatial distribution of vegetation. Within the Ammophiletea the differentiation of syntaxa occurs predominantly by edaphic factors. The most important for the distribution of associations are soil aeration and total salt regime. DCA-ordination of Cakiletea maritimae defined acidity and soil water regime as main factors. This is due to the immediate proximity to the coast. As the distance from the influence of sea water and the height of the dunes the number of xerophytic plant species increases. The soil content of the nitrogen compounds is reduced. During the preparation of the prodrome of the littoral vegetation of the National Nature Park Dzharylhatskyi, a number of nomenclature issues were raised regarding the lower syntaxa. Developing of original diagnosis and a larger amount of data from foreign publications and databases will greatly improve understanding of the content of higher syntaxa.

\section{Acknowledgements}

The autor are grateful to editors and anonymous reviewers for their valuable comments and recommendations and to Denis Davydov for English proofreading.

\section{References}

Ardamatskaya T. B., Bilinskaya O. S., Boyko M. F., Geluta V. P., Davydok V. P., Dubyna D. V., Zykov A. E., Kondratenko N. G., Kotenko A. G., Kotenko T. I., Movchan J. V., Moysienko I. I., Monchenko V. I., Seljunina, Z. V., Starenkij O. F., Tihonenko J. J., Khodosovtsev A. E., Chernjakov D. A., Shejgas I. J., Sheljag-Sosonko J. R. (2000): Biodiversity of the Jarylgach: Modern State and Ways for Conservation. - Kyiv, Zoological Herald. 240 pp. [in Ukrainian] 
Atamov V. (2008): Phytosociological characteristics the Vegetation of the Caspian's Shores in Azerbaijan. - Int. J. Bot. 4(1): 1-13. DOI: 10.3923/ijb.2008.1.13

Bohn U., Neuhäusl R., Gollub G., Hettwer C., Neuhäuslová Z., Raus T., Schlüter H., Weber H. (2004): Map of the Natural Vegetation of Europe scale 1:2500000. - Münster, Landwirtschaftsverlag.

Braun-Blanquet J. (1964): Pflanzensoziologie. Grundzuge der Vegetationskunde. 3 Aufl. - SpringerVerlag, Wien-New York, 865 pp.

Çakan H., Yilmaz K. T., Alphan H., Ünlükaplan Y. (2011): The classification and assessment of vegetation for monitoring coastal sand dune succession: the case of Tuzla in Adana, Turkey. - Turk. J. Bot. 35: 697-711. doi:10.3906/bot-1001-300

Desiatova-Shostenko N. \& Levin F. (1928): Botanichne doslidzhennya chornomors'kich kis ta ostroviv: Tendera, Orlova ta Dovgogo. - Materialy okhorony pryrody na Ukraini. 1: 3-72 [in Ukrainian]

Desiatova-Shostenko N.O. (1936): Botanichne doslidzhennya nadmors 'kich zapovidnykiv: kosy Dzharylhacha, Tendera ta ostroviv Babynoho i Smalenogo. - Tr. In-tu botaniky pry Kharkiv. derzh. un-ti. 1: 116-173 [in Ukrainian]

Didukh Ya. P. (2011): The ecological scales for the species of Ukrainian flora and their use in synphytoindication. - Kyiv. Phytosociocentre, $176 \mathrm{pp}$.

Dubyna D. V. \& Dziuba T. P. (2005): Phytocenoetic diversity of the Dzharylhach Island (Kherson region). - Ukr. Bot. J. 62(2): 128-142 [in Ukrainian]

Dubyna D. V., Neuhäuslová Z., Dziuba T. P., Shelyag-Sosonko Yu. R. (2004): Classification and prodrome of vegetation of reservoirs, floodlands and arenas of the Northern Black Sea Region. - Kyiv: Phytosociocentre. 200 pp. [in Ukrainian]

Dubyna D. V., Tymoshenko P. A., Holub V. B. (2007): Vegetation syntaxonomy of seasidedune's ecosystems of Ukraine. Cakiletea maritimae and Ammophiletea classes. Chornomorsk. Bot. J. 3(2): 19-36 [in Ukrainian] DOI: 10.14255/2308-9628/07.32/3

Dubyna D. V., Dziuba T. P., Yemelianova S. M. (2011): The coenotic diversity of the coastal psammophytic vegetation of Ukraine: a phytosozological aspect. - Chornomorsk. Bot. J. (7)3: 205-214 [in Ukrainian] DOI: 10.14255/2308-9628/11.73/1

Fagaras M. (2012): Habitats of Conservative Interest and Plant Communities in the Sandy Black Sea Coast Area of Romania and Bulgaria. - J. Environ. Prot. Ecol. 13(3A): 16881694.

Fagaras M. (2015): Embryonic shifting dunes on the Romanian Black sea coast. - Annals of the University of Craiova-Agriculture. Montanology, Cadastre Series. 45: 306-313.

Fagaras M., Niculescu M., Popoviciu R. (2015): Annual vegetation along the Black Sea shoreline within the Danube Delta Biosphere Reserve. - 15th International Multidisciplinary Scientific GeoConferences SGEM2015 3(2): 595-602 pp.

Golub V. B., Laktionov A. P., Sorokin A. N., Nikolaychuk L. F. (2006): Communities of class Cakiletea maritimae on the sea of Azov Coast of Taman Peninsula. - Notes of Samara scientific center of the Russian Academy of Sciences 8(1): 305-315 [in Russian]

Hill M.O. \& Gauch H.G. (1980): Detrented correspondence analysis, an improved ordination technique. - Vegetatio 42: 47-58. https://doi.org/10.1007/BF00048870

Chytrý M., Tichý L., Holt J. \& Botta-Dukát Z. (2002): Determination of diagnostic species with statistical fidelity measures. - J. Veg. Sci.13: 79-90. https://doi. org/10.1111/j.1654-1103.2002.tb02025.x

Kolomiychuk V.P. (2013): Trachomitum venetum (L.) Woodson subsp. sarmatiense (Woodson) Avetisjan (Apocynaceae) in the Sea of Azov region. - Ukr. Bot. J. 70(2): 248-250 [in Ukrainian] https://doi.org/10.15407/ukrbotj70.02.248

Kopecký K. \& Hejný S. (1974): A new approach to the classification of antropogenic plant communities. - Vegetatio. 29(1): 17-20. https://doi.org/10.1007/BF02390892 
Korzhenevsky V. V. \& Klyukin O. A. (1990): Rastitelnost` abrazionnych i akumulyativnych form rel'efa morskich poberezhiy i ozer Kryma. - Redkol. zhurn. Biol. nauki. Moscow, № 3822-B90. 108 pp. [in Russian]

Korzhenevsky V. V. (2001): Syntaxonomical scheme and typology of habitats of Azov and Black sea of the Crimea. - Gov. Nikita botanical garden. Yalta. 120. 107-124 [in Russian]

Herrera M., Isermann M., Knollová I., Tichý L., Tzonev R. T., Acosta A. T. R., FitzPatrick Ú., lakushenko D., Janssen J. A. M., Jiménez-Alfaro B., Kącki Z., Keizer-Sedláková I., Kolomiychuk V., Rodwell J. S., Schaminée J. H. J., Šilc U., Chytrý M. (2018): Classification of European and Mediterranean coastal dune vegetation. - Appl. Veg. Sci. 21(1): 1-27. https://doi.org/10.1111/avsc.12379

Mavrodiev E. V., Laktionov A. P., Alekseev J. E. (2015): O novyh kendyrjah jugo-vostoka Evropejskoj Rossii v svjazi s priznaniem samostojatel'nosti roda Poacynum Baill. (Apocynaceae). - Novosti Sistematiki Vysshih Rastenij. 46: 157-163 [in Russian].

Mirkin B. M. \& Rosenberg G. S. (1983): Tolkovuy slovar sovremennoy phytocenologii. Moscow, Nauka, 134 pp. [in Russian]

Mirkin B. M., Naymova L. G., Solomesh A. I. (2001): Sovremennay nayka o rastitelnosti. Moscow, Logos, 264 pp. [in Russian]

Mosyakin S. L. (2017). Taxonomic and nomenclatural notes on Pontic-Mediterranean coastal and some Australasian taxa of Salsola (Chenopodiaceae). - Ukr. Bot. J. 74(6): 521-531. https://doi.org/10.15407/ukrbotj74.06.521

Mosyakin S. L. \& Fedoronchuk M. M. (1999): Vascular Plants of Ukraine. A nomenclature Checklist. - Kiev. 345 pp.

Mucina L., Bültmann H., Dierßen K., Theurillat J.-P., Raus T., Čarni A., Šumberová K., Willner W., Dengler J., Gavilán García R., Chytrý M., Hájek M., di Pietro R., lakushenko D., Pallas J., Daniëls F. J. A., Bergmeier E., Santos Guerra A., Ermakov N., Valachovič M., Schaminée J. H. J., Lysenko T., Didukh Y. P., Pignatti S., Rodwell J. S., Capelo J., Weber H. E., Solomeshch A., Dimopoulos P., Aguiar C., Hennekens S. M., Tichý L. (2016): Vegetation of Europe: hierarchical floristic classification system of vascular plant, bryophyte, lichen, and algal communities. - Appl. Veg. Sci. 19(1): 3-264. DOI: 10.1111/avsc.12257

Naqinezhad A. (2012): Preliminary Survey of Flora and Vegetation of Sand Dune Belt in the Southern Caspian Coasts, N. Iran. - Res. J. Biol. 02(01): 23-29.

Popescu A. \& Sanda V. (1975): Etudés sur la vegétation du littoral de la Mer Noire entre Mamaia et le Cap Midia. - Revue Roum. de Biol., Ser. de Botanique, 20 (1): 7-17.

Proect orhanizatsii terytorii natsionalnoho parku «Dzharilhatskyi», okhorony, vidtvorennia ta rekreatsiynoho vykorystannia yoho pryrodnykh kompleksiv ta obiektiv (2015). - Kiev, 304 pp. [in Ukr.]

Roleček J., Tichý L., Zelený D. \& Chytrý M. (2009): Modified TWINSPAN classification in which the hierarchy respects clusters heterogeneity. - J Veg. Sci. 20(4): 596-602. DOI: 10.1111/j.1654-1103.2009.01062.x

Sanda V., Öllerer K., Burlescu F. (2008): Fitocenozele din România. - Bucureşti: Ars Docendi, $570 \mathrm{pp}$.

Sburlino G., Buffa G., Filesi L., Gamper U., Ghirelli L. (2013): Phytocoenotic diversity of the N-Adriatic coastal sand dunes. The herbaceous communities of the fixed dunes and the vegetation of the interdunal wetlands. - Plant Sociology 50(2): 57-77. DOI: $10.7338 /$ pls2013502/04

Shaposhnikova A. O. (2017): Synphytosozological investigation of vegetation of the island Dzharylgach. - Chornomorsk. Bot. J. 13(3): 278-294. [in Ukrainian] doi:10.14255/2308-9628/17.133/3. 
Solomakha V. A. (2008): Syntaxonomiya roslynnosti Ukrainy. Trete nablyzhennya. - Kyiv, Phytosociocentre, $296 \mathrm{pp}$. [in Ukrainian]

Tichý L. (2002): JUICE, software for vegetation classification. - J. Veg. Sci. 13: 451-453. DOI: 10.1111/j.1654-1103.2002.tb02069.x

Tyshenko O. V. (2006): Vegetation of the Northern Azov sea coast spits. - Kyiv, Phytosociocentre, $156 \mathrm{pp}$. [in Ukrainian]

Tzonev R. (2011): onward (continuously updated). Black Sea mobile (white) dunes. Website: http://e-ecodb.bas.bg/rdb/en/vol3/03b1.html [accessed 12.02.2018]

Umanets O. Yu. \& Solomakha I. V. (1999): The syntaxonomy of vegetation of the Chornomorssky Biosphere reserve. II. Island Tendra. - Ukrainian Phytocenological Collection. Ser. A, 2 (12-13): 63-77. [in Ukrainian]

Vicherek J. (1971): Grundriss einer Systematik der Strandgesellschaften des Schwarzen Meeres. - Folia Geobot. Phytotax. 6: 127-145. https://doi.org/10.1007/BF02851758

Weber H.E., Moravec J. \& Theurillat J.-P. (2000): International Code of Phytosociological Nomenclature. 3rd edition. - J. Veg. Sc. 11: 739-768. DOI: 10.2307/3236580

Westhoff V. \& van der Maarel E. (1973): The Braun-Blanquet approach. - In: Whittaker, R.H. (ed.): Handbook of vegetation science, part 5, Classification and ordination of communities. - Junk, The Hague: 617-726. 